\title{
Article \\ Application of PGPB Combined with Variable N Doses Affects Growth, Yield-Related Traits, N-Fertilizer Efficiency and Nutritional Status of Lettuce Grown under Controlled Condition
}

\author{
Beppe Benedetto Consentino ${ }^{1}\left(\mathbb{D}\right.$, Simona Aprile ${ }^{2}$, Youssef Rouphael ${ }^{3}\left(\mathbb{D}\right.$, Georgia Ntatsi ${ }^{4}$ (D), \\ Claudio De Pasquale ${ }^{1}$ (D), Giovanni Iapichino ${ }^{1, *}$, Pasquale Alibrandi ${ }^{5}$ and Leo Sabatino ${ }^{1}$ (D)
}

Citation: Consentino, B.B.; Aprile, S.; Rouphael, Y.; Ntatsi, G.; De Pasquale,

C.; Iapichino, G.; Alibrandi, P.;

Sabatino, L. Application of PGPB Combined with Variable N Doses Affects Growth, Yield-Related Traits, N-Fertilizer Efficiency and

Nutritional Status of Lettuce Grown under Controlled Condition. Agronomy 2022, 12, 236. https:// doi.org/10.3390/agronomy12020236 Academic Editor: Rafael A. Cañas

Received: 29 December 2021

Accepted: 17 January 2022

Published: 19 January 2022

Publisher's Note: MDPI stays neutral with regard to jurisdictional claims in published maps and institutional affiliations.

Copyright: (C) 2022 by the authors. Licensee MDPI, Basel, Switzerland. This article is an open access article distributed under the terms and conditions of the Creative Commons Attribution (CC BY) license (https:/ / creativecommons.org/licenses/by/ $4.0 /)$.
1 Dipartimento Scienze Agrarie, Alimentari e Forestali (SAAF), University of Palermo, Viale delle Scienze, Ed. 5, 90128 Palermo, Italy; beppebenedetto.consentino@unipa.it (B.B.C.); claudio.depasquale@unipa.it (C.D.P.); leo.sabatino@unipa.it (L.S.)

2 Research Center for Plant Protection and Certification, Council for Agricultural Research and Economics, SS 113 Km 245,500, 90011 Bagheria, Italy; simona.aprile@crea.gov.it

3 Department of Agricultural Sciences, University of Naples Federico II, 80055 Portici, Italy; youssef.rouphael@unina.it

4 Laboratory of Vegetable Production, Department of Crop Science, Agricultural University of Athens, 11855 Athens, Greece; ntatsi@aua.gr

5 Mugavero Fertilizers, Corso Umberto e Margherita n. 1/B Termini Imerese, 90018 Palermo, Italy; pasquale.alibrandi@mugavero.it

* Correspondence: giovanni.iapichino@unipa.it; Tel.: +39-091-2386-2215

\begin{abstract}
Nitrogen (N) fertilization is a crucial agricultural practice for boosting production traits in vegetables. However, $\mathrm{N}$ synthetic fertilizers-commonly adopted by farmers-have several counterproductive effects on the environment and on humans. The research was performed to assess the combined influence of plant growth promoting bacteria (PGPB) (Azospirillum brasilense DSM 1690, A. brasilense DSM 2298 and Pseudomonas sp. DSM 25356) and various N fertilization doses (0, 30, 60 or $120 \mathrm{~kg} \mathrm{ha}^{-1}$ ) on growth, yield, quality and nitrogen indices of lettuce in protected cultivation. Plant height, root collar diameter, number of leaves and fresh weight were enhanced by A. brasilense DSM 2298 inoculation and $\mathrm{N}$ at 30 or $60 \mathrm{~kg} \mathrm{ha}^{-1}$. Overall, soluble solids content (SSC), ascorbic acid, total phenolics, carotenoids, total chlorophyll and total sugars were augmented by the combined effect of $A$. brasilense strains and 30,60 or $120 \mathrm{~kg} \mathrm{~N} \mathrm{ha}^{-1}$. Furthermore, PGBP inoculation improved potassium $(\mathrm{K})$ and magnesium $(\mathrm{Mg})$ concentrations in leaf tissues. PGPB inoculation increased $\mathrm{N}$ leaf concentration; however, it hastened $\mathrm{N}$ indices. These results suggest that the PGPB tested can be considered an eco-friendly tool to improve lettuce yield, particularly when combined with $\mathrm{N}$ at 30 or $60 \mathrm{~kg} \mathrm{ha}^{-1}$.
\end{abstract}

Keywords: Azospirillum brasilense strains; Pseudomonas sp.; $\mathrm{N}$ fertilization rate; 'Canasta' lettuce; nutritional features; functional components; NUE

\section{Introduction}

Lettuce (Lactuca sativa L.) is a cool-season leafy vegetable grown in all regions [1,2]. Currently, more than a million hectares are cultivated with a production of more than 22 million tons [3]. Lettuce is mainly consumed as a fresh-cut, raw salad vegetable and provides a notable source of vitamins (A, B9, C and E), carotenoids, flavonoids, minerals and phenolic compounds [4-9].

Vegetable production systems need specific agricultural practices [10-12] and depend on high quantity of mineral nutrients (especially N, P and K) to enhance growth, yield and quality [13-15]. However, the incessant use of artificial fertilizers may pose threats on the ecosystem survival. In this scenario-in line with the European Green Deal strategies-plant 
biostimulants, including plant growth promoting bacteria (PGPB), are considered ecofriendly tools to hasten growth and development of vegetable crops [13,14,16-18]. PGPB consist of a group of microorganisms characterized by the ability to colonize roots, rhizosphere, and interior plant tissues $[19,20]$. PGPB can elicit plant development by influencing several processes such as nitrogen fixation, nitrate reductase activity [21], hormones synthesis (auxins, cytokinins, gibberellins, and ethylene) [22-24], solubilization of phosphate [25], and biological control of pathogens [26]. Nowadays, a wide range of PGPB genus was recognized, involving Pseudomonas, Burkholderia, Bacillus, Bradyrhizobium, Rhizobium, Gluconacetobacter, Herbaspirillum, and Azozpirillum [27-29]. Among them, Azospirillum and Pseudomonas are two free-living genus commonly found all over the world and are generally used in the agriculture sector [21,30].

As reported by Broadley et al. [31], $\mathrm{N}$ availability influences phenotypic and physiological plant parameters, which in turn affect marketability features and visual quality traits. However, the high nitrogen fertilization rate-commonly adopted by farmers-bring an upsurge in terms of nitrate content in plant tissues, causing harmful effects on the ecosystem (N leaching) and on human health. In this respect, the application of PGPB could be helpful to boost lettuce yield due to their aptitudes to enhance NUE, eliciting mineral uptake and utilization efficiency. Nevertheless, since plant response to PGPB and $\mathrm{N}$ dose are influenced by genotype and growing conditions, a detailed study is required to appraise methods and doses. To the best of our knowledge, the literature lacks information on the interaction between the PGPB tested and $\mathrm{N}$ dose in lettuce and on its effects on quantitative and qualitative traits.

Starting from the aforesaid premise, the aim of the present research was to appraise the influence of three PGPB (Azospirillum brasilense DSM 1690, A. brasilense DSM 2298 and Pseudomonas sp. DSM 25356) under four nitrogen fertilization levels $\left(0,30,60,120 \mathrm{~kg} \mathrm{ha}^{-1}\right)$ on 'Canasta' lettuce yield, as well as nutritional and functional compounds. This research offers information on the function of three different PGPB and on their influence on lettuce $\mathrm{N}$ assumption.

\section{Materials and Methods}

\subsection{Experimental Site and Material}

The investigation was accomplished during the 2021 winter-spring period at the field facilities of the Department of Agricultural, Food and Forestry Sciences of the University of Palermo (SAAF), Palermo (latitude $38^{\circ} 12^{\prime} \mathrm{N}$, longitude $13^{\circ} 36^{\prime} \mathrm{E}$, altitude $65 \mathrm{~m}$ ), located in a sub-urban area. Plants under investigation were grown in a polyethylene-covered tunnel. The tunnel was equipped with a drip irrigation system for water and nutrients distribution. A data logger was placed inside the tunnel to record microclimate data (daily maximum and minimum temperature) (Figure 1 ).

On 5 February 2021, 720 Lactuca sativa L. 'Canasta' (Syngenta Seed, Basel, Switzerland) plug plants at 3-4 true leaves stage were transplanted adopting an inter-/intra-row spacing of $0.25 \mathrm{~m}$ and obtaining a density of 16 plant $\mathrm{m}^{-2}$. On 6 April 2021, all plants were harvested by cutting the collar, and then the external damaged leaves were removed. Throughout the whole cultivation cycle, all plant needs (water, nutrients, and cultivation practices) were covered, as recommended by Tesi [32]. The soil was a medium-textured soil at $\mathrm{pH}$ 7.1, containing $1.7 \%$ total nitrogen and $3.1 \%$ organic matter.

\subsection{Design and Procedure}

Four $\mathrm{N}$ levels $\left(0,30,60\right.$, or $\left.120 \mathrm{~kg} \mathrm{ha}^{-1}\right)$ were combined with four microorganism treatments (not inoculated or inoculated with A. brasilense DSM 1690, A. brasilense DSM 2298, and Pseudomonas sp. DSM 25356) in a two factorial experiment rendering 16 treatments. The treatments were set in a complete randomized block design, and they were replicated three times. Each experimental block enclosed 15 lettuce plants for a total of 720 plants (16 treatments $\times 3$ blocks $\times 15$ plants). 


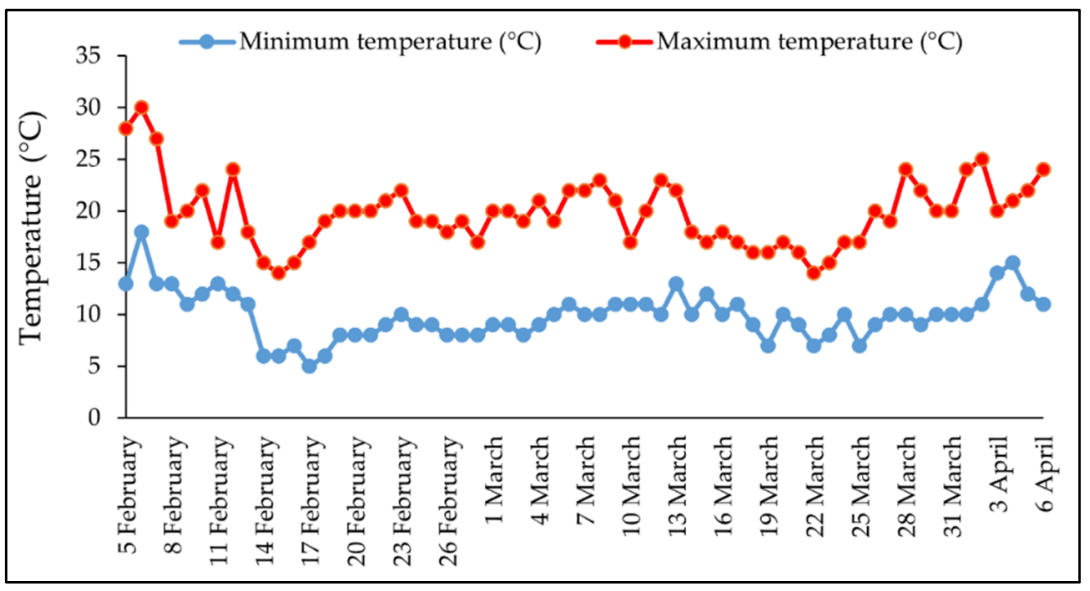

Figure 1. Maximum and minimum temperatures inside the tunnel from 5 February 2021 to 6 April 2021.

The nitrogen fertilization was accomplished using Nitrosol $34^{\circledR}$ (Mugavero fertilizers, Italy) and it was applied weekly starting one week after transplant. This nitrogen fertilizer contained $34 \%$ of nitrogen in the form of ammonium nitrate $\left(\mathrm{NH}_{4} \mathrm{NO}_{3}\right)$, distributed via a fertigation system.

The PGPB strains adopted for this study are deposited in the Leibniz Institute DSMZ (German Collection of Microorganisms and Cell Cultures $\mathrm{GmbH}$ ). Each strain was grown in nutrient agar plate. All Pre-cultures were obtained inoculating pure single colonies in 100 -mL Erlenmeyer flasks at $28^{\circ} \mathrm{C}$ with $10 \mathrm{~mL}$ of nutrient broth (NB), containing $5.0 \mathrm{~g} \mathrm{~L}^{-1}$ of peptone and $3.0 \mathrm{~g} \mathrm{~L}^{-1}$ of meat extract, spinning at $150 \mathrm{rpm}$ in a centrifuge for $24 \mathrm{~h}$ (Azospirillum brasilense) and $48 \mathrm{~h}$ (Pseudomonas sp.).

After the incubation time, each bacterial culture was collected in a $50 \mathrm{~mL}$ tube and centrifuged at $4000 \mathrm{rpm}$ for $10 \mathrm{~min}$, then the supernatant was removed, and the pellet resuspended in $0.8 \% \mathrm{NaCl}$. The optical density was corrected up to $1.0(540 \mathrm{~nm})$ for about $10^{9} \mathrm{CFU} / \mathrm{mL}$. A volume of $2 \mathrm{~mL}$ of this suspension was inoculated in 500-mL flasks with $120 \mathrm{~mL}$ of nutrient broth.

Growth was established optically at $600 \mathrm{~nm}$ (Beckman DU730 spectrophotometer). Finally, CFU per millilitre was assessed by multiplying the number of colonies by the dilution factor.

Each of the three bacteria was inoculated to the plants during the transplanting phase by soaking the roots for $2 \mathrm{~min}$ in a solution containing $10 \mathrm{~mL} \mathrm{~L}^{-1}$ of microorganism suspension; in addition, 15 days after transplant, the inoculation was repeated in the soil using $100 \mathrm{~mL}$ of solution. Control plants only received water treatment.

\subsection{Measurements}

Determinations on agronomic and colorimetric traits were performed on six samples, casually chosen from each replicate. Once 'Canasta' plants were harvested, head fresh weight, number of leaves, collar diameter and plant height values were collected. CIELab colour coordinates were appraised via a colorimeter (Chroma-meter CR-400, Minolta corporation Ltd., Osaka, Japan).

To appraise head dry matter content, the samples were put in a thermo-aerated oven at $105^{\circ} \mathrm{C}$ until constant weight. The dry matter value was expressed as percentage using the following formula: dry weight $(\mathrm{g}) /$ fresh weight $(\mathrm{g})^{*} 100$.

All analysis on plant nutritional and bioactive traits were appraised on six samples, arbitrarily chosen from each biological replicate. Soluble solids content values (SSC) were obtained through a refractometer (MTD-045 nD, Taipei, Taiwan) and the results were presented as ${ }^{\circ}$ Brix.

Plant ascorbic acid content was determined by employing a Reflectometer RQflex10 Reflectoquant ${ }^{\circledR}$ (Sigma-Aldrich, Saint Louis, MO, USA) and Reflectoquant Ascorbic Acid 
Test Strips (Merck, Darmstadt, Germany). Total phenolic values were appraised by the Folin-Ciocalteu method [33]. Total sugar concentration was evaluated following the method described by Serna et al. [34].

Total chlorophyll and carotenoid contents were assessed spectrophotometrically following the procedure of Costache et al. [35]. Both pigments values were expressed as mg $100 \mathrm{~g}^{-1}$ of fresh weight. Total nitrogen $(\mathrm{N})$ was evaluated via the Kjeldahl method. Phosphorous $(\mathrm{P})$, potassium $(\mathrm{K})$, calcium $(\mathrm{Ca})$ and magnesium $(\mathrm{Mg})$ concentrations were appraised following the Fogg and Wilkinson method [36] and the Morand and Gullo method [37]. The entire mineral profile data were reported as $\mathrm{mg} \mathrm{g}^{-1}$ dry weight.

$\mathrm{N}$ indices (nitrogen use efficiency and nitrogen uptake efficiency) were calculated as follow: Nitrogen use efficiency $(\mathrm{NUE})=$ yield $(\mathrm{t}) /$ nitrogen application rate $(\mathrm{kg})$, nitrogen uptake efficiency $(\mathrm{UE})=$ plant nitrogen content $(\mathrm{kg}) /$ nitrogen application rate $(\mathrm{kg})$.

\subsection{Statistical Analyses}

All collected data were analysed (StatSoft, Inc., Chicago, IL, USA) through two-way analysis of variance (ANOVA) by the SPSS software v. 20 (StatSoft, Inc., Chicago, IL, USA), setting nitrogen doses and microorganisms as main factors. For means separation, Tukey's honestly significant difference (HSD) test at $p \leq 0.05$ was used. Data expressed as percentages were subjected to arcsin transformation before ANOVA analysis $\left(\varnothing=\arcsin (\mathrm{p} / 100)^{1 / 2}\right)$.

\section{Results}

\subsection{Implications of PGPB and Nitrogen Dose on Yield and Yield-Related Features}

Plant height, root collar diameter, number of leaves, head fresh weight and head dry matter percentage were influenced by PGPB application and nitrogen dose (Table 1). Moreover, ANOVA indicated a significant effect of the interaction PGPB $\times$ N (Table 1).

Table 1. Interaction effect of plant growth promoting bacteria (PGPB) (A. brasilense DSM 1690, A. brasilense DSM 2298 and Pseudomonas sp. DSM 25356) and nitrogen dose (0, 30, 60 and $\left.120 \mathrm{~kg} \mathrm{ha}^{-1}\right)$ on plant height, root collar diameter, number of leaves, head fresh weight and head dry weight of 'Canasta' lettuce.

\begin{tabular}{|c|c|c|c|c|c|c|c|c|c|c|c|}
\hline \multicolumn{2}{|r|}{ Treatments } & \multicolumn{2}{|c|}{ Plant Height (cm) } & \multicolumn{2}{|c|}{$\begin{array}{c}\text { Root Collar } \\
\text { Diameter }(\mathrm{mm})\end{array}$} & \multicolumn{2}{|c|}{$\begin{array}{l}\text { Number of Leaves } \\
\left(\text { No. plant }{ }^{-1}\right)\end{array}$} & \multicolumn{2}{|c|}{$\begin{array}{l}\text { Head Fresh Weight } \\
\left.\text { (g plant }^{-1}\right)\end{array}$} & \multicolumn{2}{|c|}{$\begin{array}{l}\text { Head Dry } \\
\text { Matter (\%) }\end{array}$} \\
\hline $\mathrm{N}$ dose $\left(\mathrm{kg} \mathrm{ha}^{-1}\right)$ & PGPB & & & & & & & & & & \\
\hline \multirow[t]{4}{*}{ 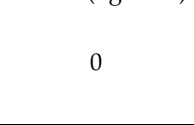 } & Non-inoculated & 24.4 & $\mathrm{~g}$ & 16.8 & $\mathrm{i}$ & 24.0 & $\mathrm{~d}$ & 292.9 & 1 & 12.5 & $\mathrm{~g}$ \\
\hline & A. brasilense DSM 1690 & 27.9 & $\mathrm{~d}$ & 20.1 & $\mathrm{~h}$ & 28.3 & $\mathrm{~b}$ & 633.4 & $\mathrm{~h}$ & 14.2 & c \\
\hline & A. brasilense DSM 2298 & 30.2 & c & 28.5 & a & 25.7 & c & 637.4 & $\mathrm{~h}$ & 13.8 & d \\
\hline & Pseudomonas sp. DSM 25356 & 25.2 & $\mathrm{f}$ & 12.8 & j & 23.7 & e & 457.0 & $\mathrm{k}$ & 13.3 & e \\
\hline \multirow{4}{*}{30} & Non-inoculated & 28.4 & $\mathrm{~d}$ & 28.5 & a & 24.7 & $\mathrm{~cd}$ & 565.0 & $\mathrm{j}$ & 12.7 & $\mathrm{~g}$ \\
\hline & A. brasilense DSM 1690 & 31.5 & $\mathrm{~b}$ & 22.9 & $\mathrm{f}$ & 25.3 & c & 751.3 & c & 14.7 & c \\
\hline & A. brasilense DSM 2298 & 32.8 & a & 24.1 & e & 24.7 & $\mathrm{~cd}$ & 835.3 & a & 14.0 & c \\
\hline & Pseudomonas sp. DSM 25356 & 28.0 & d & 21.8 & $g$ & 30.0 & $\mathrm{a}$ & 653.5 & g & 13.6 & de \\
\hline \multirow{4}{*}{60} & Non-inoculated & 29.0 & c & 28.9 & a & 28.7 & $a b$ & 631.1 & $\mathrm{~h}$ & 13.1 & $\mathrm{f}$ \\
\hline & A. brasilense DSM 1690 & 32.0 & a & 23.8 & ef & 30.3 & $\mathrm{a}$ & 603.5 & $\mathrm{i}$ & 14.9 & $\mathrm{~b}$ \\
\hline & A. brasilense DSM 2298 & 26.9 & e & 25.3 & $\mathrm{~d}$ & 26.0 & c & 675.3 & e & 14.3 & c \\
\hline & Pseudomonas sp. DSM 25356 & 30.2 & c & 27.1 & c & 25.7 & c & 725.6 & $\mathrm{~d}$ & 13.8 & d \\
\hline \multirow{4}{*}{120} & Non-inoculated & 30.0 & c & 26.0 & $\mathrm{~d}$ & 26.7 & bc & 630.1 & $\mathrm{~h}$ & 13.5 & e \\
\hline & A. brasilense DSM 1690 & 25.8 & $\mathrm{f}$ & 28.0 & $\mathrm{~b}$ & 27.7 & $\mathrm{~b}$ & 658.1 & $\mathrm{f}$ & 15.5 & a \\
\hline & A. brasilense DSM 2298 & 29.8 & $\mathrm{~cd}$ & 24.2 & e & 26.3 & c & 816.3 & $\mathrm{~b}$ & 15.1 & $\mathrm{~b}$ \\
\hline & Pseudomonas sp. DSM 25356 & 30.3 & $\mathrm{c}$ & 22.7 & $\mathrm{f}$ & 29.7 & a & 829.4 & a & 13.8 & d \\
\hline \multicolumn{12}{|c|}{ Significance } \\
\hline \multicolumn{2}{|r|}{ Nitrogen $(\mathrm{N})$} & \multicolumn{2}{|c|}{$* * *$} & \multicolumn{2}{|c|}{$* * *$} & \multicolumn{2}{|c|}{$* * *$} & \multicolumn{2}{|c|}{$* * *$} & \multicolumn{2}{|c|}{$* * *$} \\
\hline & PGPB & \multicolumn{2}{|c|}{$* * *$} & \multicolumn{2}{|c|}{$* * *$} & \multicolumn{2}{|c|}{$* * *$} & \multicolumn{2}{|c|}{$* * *$} & \multicolumn{2}{|c|}{$* * *$} \\
\hline & $\mathrm{N} \times \mathrm{PGPB}$ & \multicolumn{2}{|c|}{$* * *$} & \multicolumn{2}{|c|}{$* * *$} & \multicolumn{2}{|c|}{$* * *$} & \multicolumn{2}{|c|}{$* * *$} & \multicolumn{2}{|c|}{$* * *$} \\
\hline
\end{tabular}

Means followed by the same letter for treatments are not significantly different accordingly to Tukey's honestly significant difference (HSD) test at $p \leq 0.05$. Significance levels: ${ }^{* *}$ significant at $p \leq 0.001$.

The highest plant height was observed in plants from the combination $30 \times A$. brasilense DSM 2298 and the combination $60 \times$ A. brasilense DSM 1690, followed by those supplied 
with $30 \mathrm{~kg} \mathrm{~N} \mathrm{ha}^{-1}$ and treated with $A$. brasilense DSM 1690 . Control plants $\left(0 \mathrm{~kg} \mathrm{~N}^{-1} \times\right.$ noninoculated) displayed the lowest values (Table 1).

Both plants supplied with $A$. brasilense DSM 2298 and treated with $0 \mathrm{~kg} \mathrm{~N} \mathrm{ha}^{-1}$ and those non-inoculated and supplied with 30 or $60 \mathrm{~kg} \mathrm{~N} \mathrm{ha}^{-1}$ had the highest root collar diameter, followed by plants subjected to the highest $\mathrm{N}$ level and inoculated with A. brasilense DSM 1690 (Table 1). Lettuce plants from the $0 \times$ Pseudomonas sp. DSM 25356 combination had the lowest root collar diameter.

The highest number of leaves was appraised in the combinations: $30 \times$ Pseudomonas sp. DSM 25356, $60 \times A$. brasilense DSM 1690 and $120 \times$ Pseudomonas sp. DSM 25356, followed by those with $\mathrm{N}$ at 60 or $120 \mathrm{~kg} \mathrm{~N}^{-1}$ and A. brasilense DSM 1690 (Table 1). Nevertheless, plants from non-inoculated plots and treated with $60 \mathrm{~kg} \mathrm{~N}^{-1}$ did not significantly diverge neither from plants from the combinations $30 \times$ Pseudomonas sp. DSM 25356, $60 \mathrm{~kg} \times$ A. brasilense DSM 1690 and $120 \times$ Pseudomonas sp. DSM 25356 nor from those supplied with 60 or $120 \mathrm{~kg} \mathrm{~N} \mathrm{ha}^{-1}$ and inoculated with A. brasilense DSM 1690. The lowest number of leaves was observed in plants treated with $0 \mathrm{~kg} \mathrm{~N}^{-1}$ and inoculated with Pseudomonas sp. DSM 25356 (Table 1).

Plants fertigated with $30 \mathrm{~kg} \mathrm{~N}^{-1}$ and treated with A. brasilense DSM 2298 and those exposed to $120 \times$ Pseudomonas sp. DSM 25356 combination had the highest head fresh weight, followed by plants from plots fertigated with the $120 \mathrm{~kg} \mathrm{~N}^{-1}$ and inoculated with $A$. brasilense DSM 2298, which in turn revealed higher values than plants from the combination $30 \times$ A. brasilense DSM 1690 (Table 1). Control plants had the lowest head fresh weight.

The greatest head dry matter percentage was found in plants fertigated with the highest nitrogen dose and inoculated with A. brasilense DSM 1690, followed by those exposed to $120 \mathrm{~kg} \mathrm{~N} \mathrm{ha}^{-1}$ and inoculated with A. brasilense DSM 2298 (Table 1). The lowest head dry matter percentage was observed in control plants and in non-inoculated plants fertigated with $30 \mathrm{~kg} \mathrm{~N} \mathrm{ha}^{-1}$.

\subsection{Implications of PGPB and Nitrogen Dose on Leaf Colour, Nutritional and Functional Components and Mineral Concentrations}

ANOVA showed that SSC and CIELab colour parameters were significantly influenced by PGPB and nitrogen dose treatments and by their interaction (Table 2).

Plants from the $30 \times A$. brasilense DSM 1690, $60 \times$ A. brasilense DSM 2298 and $120 \times$ Pseudomonas sp. DSM 25356 combinations had the highest SSC (Table 2), whereas, non-inoculated plants fertigated with $30 \mathrm{~kg} \mathrm{~N} \mathrm{ha}^{-1}$ had the lowest SSC.

Plants supplied with $30 \mathrm{~kg} \mathrm{~N}^{-1}$ and treated with A. brasilense DSM 2298 had the highest a* values, whereas non-fertigated plants inoculated with A. brasilense DSM 1690 had the lowest $\mathrm{a}^{*}$ values. Plants from the combinations $60 \times A$. brasilense DSM 1690 had the highest $\mathrm{b}^{*}$ (Table 2), while, non-fertigated plants inoculated with brasilense DSM 2298 had the lowest $b^{*}$.

The highest $\mathrm{L}^{*}$ value was observed in plants fertigated with $120 \mathrm{~kg} \mathrm{~N} \mathrm{ha}^{-1}$ and treated with Pseudomonas sp. DSM 25356, followed by that detected in plants not fertigated and exposed to Pseudomonas sp. DSM 25356 (Table 2). The lowest lightness value was recorded in plants treated with A. brasilense DSM 1690 and not fertigated with N.

As regard total sugars, ANOVA did not show a significant effect of the interaction $\mathrm{N} \times \mathrm{PGPB}$ (Figure 2). Averaged over PGPB, total sugars level was not affected by nitrogen dose (Figure 2).

Contrariwise, when averaged over nitrogen dose, sugar content was significantly affected by inoculation. Plants inoculated with $A$. brasilense DSM 1690 revealed the highest values, followed by those inoculated with $A$. brasilense DSM 2298, which in turn showed a higher total sugar concentration than those treated with Pseudomonas sp. DSM 25356 (Figure 2). Non-inoculated plants had the lowest total sugar content. 
Table 2. Interaction effect of plant growth promoting bacteria (PGPB) (A. brasilense DSM 1690, A. brasilense DSM 2298 and Pseudomonas sp. DSM 25356) and nitrogen dose (0, 30, 60 and $\left.120 \mathrm{~kg} \mathrm{ha}^{-1}\right)$ on soluble solid content (SSC), $\mathrm{a}^{*}, \mathrm{~b}^{*}$ and $\mathrm{L}^{*}$ of 'Canasta' lettuce.

\begin{tabular}{|c|c|c|c|c|c|c|c|c|c|}
\hline \multicolumn{2}{|r|}{ Treatments } & \multicolumn{2}{|c|}{ SSC ( ${ }^{\circ}$ Brix $)$} & \multicolumn{2}{|c|}{$a^{*}$} & \multicolumn{2}{|c|}{$\mathbf{b}^{*}$} & \multicolumn{2}{|c|}{$\mathrm{L}^{*}$} \\
\hline $\mathrm{N}$ dose $\left(\mathrm{kg} \mathrm{ha}^{-1}\right)$ & PGPB & & & & & & & & \\
\hline \multirow[t]{4}{*}{ 18 } & Non-inoculated & 4.1 & $\mathrm{~b}$ & -19.32 & c & 26.87 & c & 46.50 & $\mathrm{~cd}$ \\
\hline & A. brasilense DSM 1690 & 4.1 & $\mathrm{~b}$ & -20.67 & d & 28.30 & c & 41.70 & $\mathrm{e}$ \\
\hline & A. brasilense DSM 2298 & 4.0 & c & -17.09 & $\mathrm{~b}$ & 22.58 & $\mathrm{e}$ & 45.39 & $\mathrm{~d}$ \\
\hline & Pseudomonas sp. DSM 25356 & 4.1 & a & -19.40 & c & 32.46 & a & 53.10 & $\mathrm{~b}$ \\
\hline \multirow{4}{*}{30} & Non-inoculated & 3.2 & e & -17.26 & b & 24.85 & $\mathrm{~d}$ & 52.17 & $\mathrm{~b}$ \\
\hline & A. brasilense DSM 1690 & 4.4 & a & -19.34 & c & 32.61 & a & 44.65 & d \\
\hline & A. brasilense DSM 2298 & 4.2 & $\mathrm{~b}$ & -11.30 & $\mathrm{a}$ & 24.39 & d & 44.36 & $\mathrm{~d}$ \\
\hline & Pseudomonas sp. DSM 25356 & 4.1 & $\mathrm{~b}$ & -17.96 & $\mathrm{~b}$ & 33.34 & a & 52.11 & $\mathrm{~b}$ \\
\hline \multirow{4}{*}{60} & Non-inoculated & 3.7 & $\mathrm{~d}$ & -17.87 & $\mathrm{~b}$ & 30.55 & $\mathrm{~b}$ & 52.96 & $\mathrm{~b}$ \\
\hline & A. brasilense DSM 1690 & 4.2 & $\mathrm{~b}$ & -20.74 & d & 33.67 & a & 47.36 & c \\
\hline & A. brasilense DSM 2298 & 4.3 & a & -18.82 & c & 25.11 & d & 44.67 & d \\
\hline & Pseudomonas sp. DSM 25356 & 4.0 & c & -19.63 & c & 31.15 & $\mathrm{~b}$ & 47.60 & c \\
\hline \multirow{4}{*}{120} & Non-inoculated & 4.2 & $\mathrm{~b}$ & -16.81 & b & 25.74 & $\mathrm{~d}$ & 45.50 & $\mathrm{~d}$ \\
\hline & A. brasilense DSM 1690 & 4.1 & $\mathrm{~b}$ & -17.13 & $\mathrm{~b}$ & 25.49 & d & 48.05 & c \\
\hline & A. brasilense DSM 2298 & 4.1 & $\mathrm{~b}$ & -20.22 & d & 23.18 & e & 44.18 & $\mathrm{~d}$ \\
\hline & Pseudomonas sp. DSM 25356 & 4.5 & a & -17.00 & $\mathrm{~b}$ & 26.17 & c & 54.31 & a \\
\hline \multicolumn{10}{|c|}{ Significance } \\
\hline \multicolumn{2}{|r|}{ Nitrogen $(\mathrm{N})$} & \multicolumn{2}{|c|}{$*$} & \multicolumn{2}{|c|}{$* * *$} & \multicolumn{2}{|c|}{$* * *$} & \multicolumn{2}{|c|}{$* * *$} \\
\hline \multirow{2}{*}{\multicolumn{2}{|c|}{$\begin{array}{c}\text { PGPB } \\
\mathrm{N} \times \text { PGPB }\end{array}$}} & \multicolumn{2}{|c|}{$* * *$} & \multicolumn{2}{|c|}{$* * *$} & \multicolumn{2}{|c|}{$* * *$} & \multicolumn{2}{|c|}{$* * *$} \\
\hline & & \multicolumn{2}{|c|}{$* * *$} & \multicolumn{2}{|c|}{$* * *$} & \multicolumn{2}{|c|}{$* * *$} & \multicolumn{2}{|c|}{$* * *$} \\
\hline
\end{tabular}

Means followed by the same letter for treatments are not significantly different accordingly to Tukey's honestly significant difference (HSD) test at $p \leq 0.05$. Significance levels: * significant at $p \leq 0.05 ;{ }^{* * *}$ significant at $p \leq 0.001$.

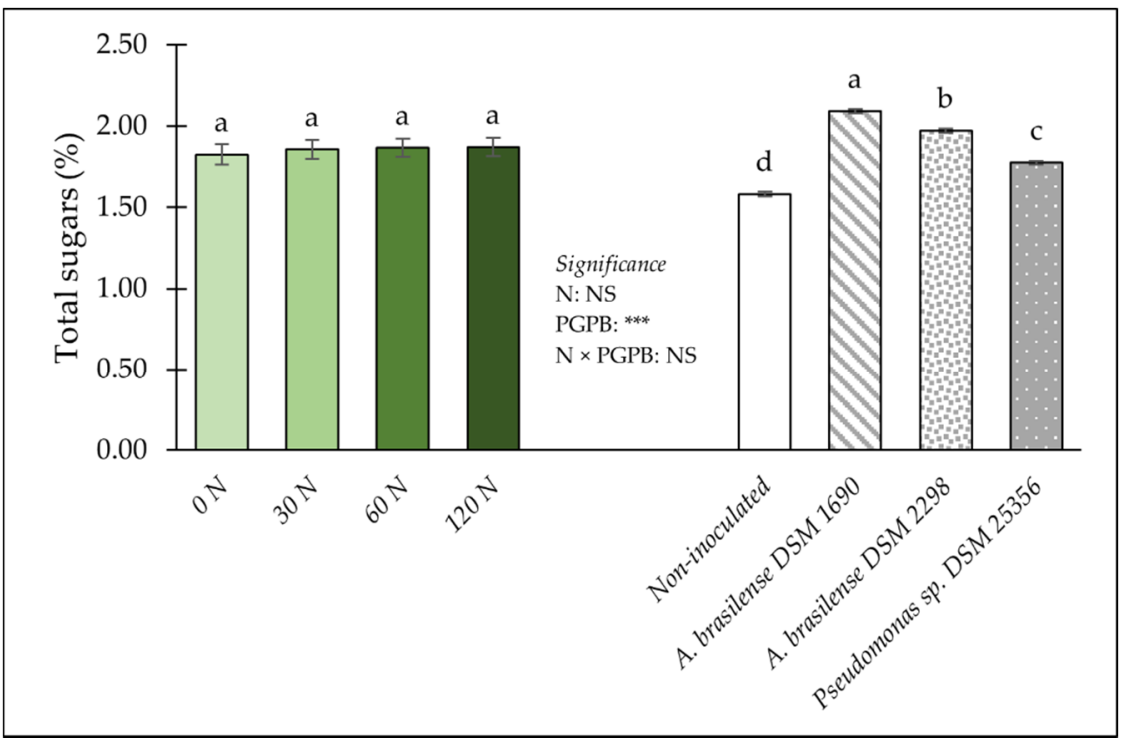

Figure 2. Impact of plant growth promoting bacteria (PGPB) (A. brasilense DSM 1690, A. brasilense DSM 2298 and Pseudomonas sp. DSM 25356) and nitrogen dose $\left(0,30,60\right.$ and $\left.120 \mathrm{~kg} \mathrm{ha}^{-1}\right)$ on total sugars of 'Canasta' lettuce. Means followed by the same letter for treatments are not significantly different accordingly to Tukey's honestly significant difference (HSD) test at $p \leq 0.05$. Significance levels: NS non-significant; ${ }^{* * *}$ significant at $p \leq 0.001$. Bars indicate standard error. $0 \mathrm{~N}, 30 \mathrm{~N}, 60 \mathrm{~N}$ and $120 \mathrm{~N}$ represent $0,30,60$ and $120 \mathrm{~kg} \mathrm{~N}^{-1}$, respectively.

As regard ascorbic acid, total phenolics, carotenoids, total chlorophyll and nitrogen, ANOVA showed a significant effect of the interaction between nitrogen dose and PGPB application (Table 3). 
Table 3. Interaction effect of plant growth promoting bacteria (PGPB) (A. brasilense DSM 1690, A. brasilense DSM 2298 and Pseudomonas sp. DSM 25356) and nitrogen dose (0, 30, 60 and $\left.120 \mathrm{~kg} \mathrm{ha}^{-1}\right)$ on ascorbic acid, total phenolics, carotenoids, total chlorophyll and nitrogen $(\mathrm{N})$ of 'Canasta' lettuce.

\begin{tabular}{|c|c|c|c|c|c|c|c|c|c|c|c|}
\hline \multirow{2}{*}{\multicolumn{2}{|c|}{$\begin{array}{l}\text { Treatments } \\
\text { PGPB }\end{array}$}} & \multicolumn{2}{|c|}{$\begin{array}{l}\text { Ascorbic Acid } \\
\left(\mathrm{mg} \mathrm{g}^{-1} \mathrm{fw}\right)\end{array}$} & \multicolumn{2}{|c|}{$\begin{array}{l}\text { Total Phenolics } \\
\left(\mu g g^{-1} \mathrm{fw}\right)\end{array}$} & \multicolumn{2}{|c|}{$\begin{array}{c}\text { Carotenoids } \\
\left(\mathrm{mg} 100 \mathrm{~g}^{-1} \mathrm{fw}\right)\end{array}$} & \multicolumn{2}{|c|}{$\begin{array}{l}\text { Total Chlorophyll } \\
\left(\mathrm{mg} 100 \mathrm{~g}^{-1} \mathrm{fw}\right)\end{array}$} & \multicolumn{2}{|c|}{$N\left(\mathrm{mg} \mathrm{g}^{-1} \mathrm{dw}\right)$} \\
\hline & & & & & & & & & & & \\
\hline \multirow[t]{4}{*}{ 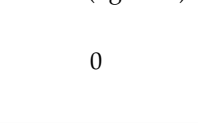 } & Non-inoculated & 28.28 & $\mathrm{f}$ & 47.90 & d & 14.94 & $\mathrm{~g}$ & 33.47 & $\mathrm{~h}$ & 25.66 & $\mathrm{i}$ \\
\hline & A. brasilense DSM 1690 & 39.06 & a & 55.38 & $\mathrm{a}$ & 17.52 & $\mathrm{e}$ & 38.32 & c & 30.27 & $\mathrm{f}$ \\
\hline & A. brasilense DSM 2298 & 36.84 & $\mathrm{~b}$ & 51.15 & $\mathrm{~b}$ & 17.23 & $\mathrm{e}$ & 36.74 & $\mathrm{f}$ & 28.98 & g \\
\hline & Pseudomonas sp. DSM 25356 & 35.65 & c & 49.76 & c & 16.70 & $\mathrm{f}$ & 35.81 & g & 25.56 & $\mathrm{i}$ \\
\hline \multirow{4}{*}{30} & Non-inoculated & 28.14 & $\mathrm{f}$ & 47.52 & $\mathrm{~d}$ & 15.59 & $\mathrm{~g}$ & 35.37 & $\mathrm{~g}$ & 28.67 & $\mathrm{~h}$ \\
\hline & A. brasilense DSM 1690 & 39.18 & a & 55.65 & $\mathrm{a}$ & 20.96 & $\mathrm{~b}$ & 40.50 & $\mathrm{~b}$ & 33.46 & $\mathrm{~d}$ \\
\hline & A. brasilense DSM 2298 & 36.51 & $\mathrm{~b}$ & 51.51 & $\mathrm{~b}$ & 18.67 & $\mathrm{~d}$ & 37.67 & d & 30.18 & f \\
\hline & Pseudomonas sp. DSM 25356 & 34.94 & d & 49.80 & c & 17.20 & ef & 36.96 & e & 29.43 & $\mathrm{~g}$ \\
\hline \multirow{4}{*}{60} & Non-inoculated & 27.78 & $\mathrm{f}$ & 47.52 & $\mathrm{~d}$ & 15.52 & $\mathrm{~g}$ & 35.45 & $g$ & 30.46 & $\mathrm{f}$ \\
\hline & A. brasilense DSM 1690 & 39.35 & $\mathrm{a}$ & 55.49 & $\mathrm{a}$ & 22.88 & a & 40.43 & $\mathrm{~b}$ & 35.47 & $\mathrm{~b}$ \\
\hline & A. brasilense DSM 2298 & 36.46 & $\mathrm{bc}$ & 51.55 & $\mathrm{~b}$ & 19.52 & c & 37.86 & d & 31.55 & e \\
\hline & Pseudomonas sp. DSM 25356 & 34.44 & $\mathrm{~d}$ & 49.61 & c & 17.23 & e & 36.88 & e & 31.69 & e \\
\hline \multirow{4}{*}{120} & Non-inoculated & 27.22 & g & 45.54 & e & 15.48 & g & 35.41 & g & 34.36 & c \\
\hline & A. brasilense DSM 1690 & 37.27 & $\mathrm{~b}$ & 52.01 & $\mathrm{~b}$ & 22.79 & a & 42.53 & a & 38.59 & a \\
\hline & A. brasilense DSM 2298 & 34.99 & $\mathrm{~d}$ & 50.26 & c & 19.48 & c & 38.76 & c & 34.70 & c \\
\hline & Pseudomonas sp. DSM 25356 & 30.98 & $\mathrm{e}$ & 48.18 & $\mathrm{~d}$ & 17.36 & $\mathrm{e}$ & 37.28 & e & 35.52 & $\mathrm{~b}$ \\
\hline \multicolumn{12}{|c|}{ Significance } \\
\hline \multicolumn{2}{|r|}{ Nitrogen $(\mathrm{N})$} & \multicolumn{2}{|c|}{$* * *$} & \multicolumn{2}{|c|}{$* * *$} & \multicolumn{2}{|c|}{$* * *$} & \multicolumn{2}{|c|}{$* * *$} & \multicolumn{2}{|c|}{$* * *$} \\
\hline & PGPB & \multicolumn{2}{|c|}{$* * *$} & \multicolumn{2}{|c|}{$* * *$} & \multicolumn{2}{|c|}{$* * *$} & \multicolumn{2}{|c|}{$* * *$} & \multicolumn{2}{|c|}{$* * *$} \\
\hline & $\mathrm{N} \times \mathrm{PGPB}$ & \multicolumn{2}{|c|}{$* * *$} & \multicolumn{2}{|c|}{$* *$} & \multicolumn{2}{|c|}{$* * *$} & \multicolumn{2}{|c|}{$* * *$} & \multicolumn{2}{|c|}{$* * *$} \\
\hline
\end{tabular}

Means followed by the same letter for treatments are not significantly different accordingly to Tukey's honestly significant difference (HSD) test at $p \leq 0.05$. Significance levels: ${ }^{* *}$ significant at $p \leq 0.005 ;{ }^{* * *}$ significant at $p \leq 0.001$.

Plants inoculated with A. brasilense DSM 1690 and fertigated with 0,30 or $60 \mathrm{~kg} \mathrm{~N} \mathrm{ha}^{-1}$ had a higher ascorbic acid concentration than those treated with A. brasilense DSM 2298 and fertigated with 0,30 or $60 \mathrm{~kg} \mathrm{~N} \mathrm{ha}^{-1}$ (Table 3). The lowest ascorbic acid concentration was detected in non-inoculated plants fertigated with the highest nitrogen dose. Data on total phenolics followed the trend described for ascorbic acid (Table 3).

Plants inoculated with A. brasilense DSM 1690 and fertigated with 60 or $120 \mathrm{~kg} \mathrm{~N} \mathrm{ha}^{-1}$ had a higher carotenoids content (Table 3) than those fertigated with $30 \mathrm{~kg} \mathrm{~N} \mathrm{ha}^{-1}$ and treated with A. brasilense DSM 1690. Regardless N dosages, non-inoculated plants revealed the lowest carotenoids concentrations.

Lettuce plants supplied with the highest $\mathrm{N}$ dosage and inoculated with $A$. brasilense DSM 1690 had a higher total chlorophyll concentration (Table 3) than those inoculated with the same PGPB strain and fertigated with 30 or $60 \mathrm{~kg} \mathrm{~N} \mathrm{ha}^{-1}$. The lowest values were detected in control plants.

Plants exposed to $120 \mathrm{~kg} \mathrm{~N} \mathrm{ha}^{-1}$ and inoculated with A. brasilense DSM 1690 had the highest $\mathrm{N}$ concentration (Table 3), followed by those fertigated with $60 \mathrm{~kg} \mathrm{~N} \mathrm{ha}^{-1}$ and inoculated with $A$. brasilense DSM 1690. Control plants and those from non-fertigated plots and inoculated with Pseudomonas sp. DSM 25356 had the lowest $\mathrm{N}$ concentration values.

ANOVA for $\mathrm{P}, \mathrm{K}, \mathrm{Ca}$ and $\mathrm{Mg}$ did not reveal a significant effect of the interaction $\mathrm{N} \times \mathrm{PGPB}$ (Figure 3 ).

Regardless of the PGPB application, plants fertigated with 60 or $120 \mathrm{~kg} \mathrm{~N} \mathrm{ha}^{-1}$ had the highest $\mathrm{P}$ concentration (Figure $3 \mathrm{~A}$ ), whereas plants not supplied with nitrogen showed the lowest $\mathrm{P}$ concentration values. Conversely, when averaged over nitrogen fertigation, PGPB application did not significantly affected P concentration.

Nitrogen fertigation level did not significantly affect $\mathrm{K}$ concentration (Figure 3B). Contrariwise, PGPB significantly affected the aforementioned parameter. The highest $\mathrm{K}$ concentration was observed in plants inoculated with A. brasilense DSM 1690, followed by that detected in plants treated with the other strain of $A$. brasilense (DSM 2298). The lowest $\mathrm{K}$ concentration was recorded in non-inoculated plants. 


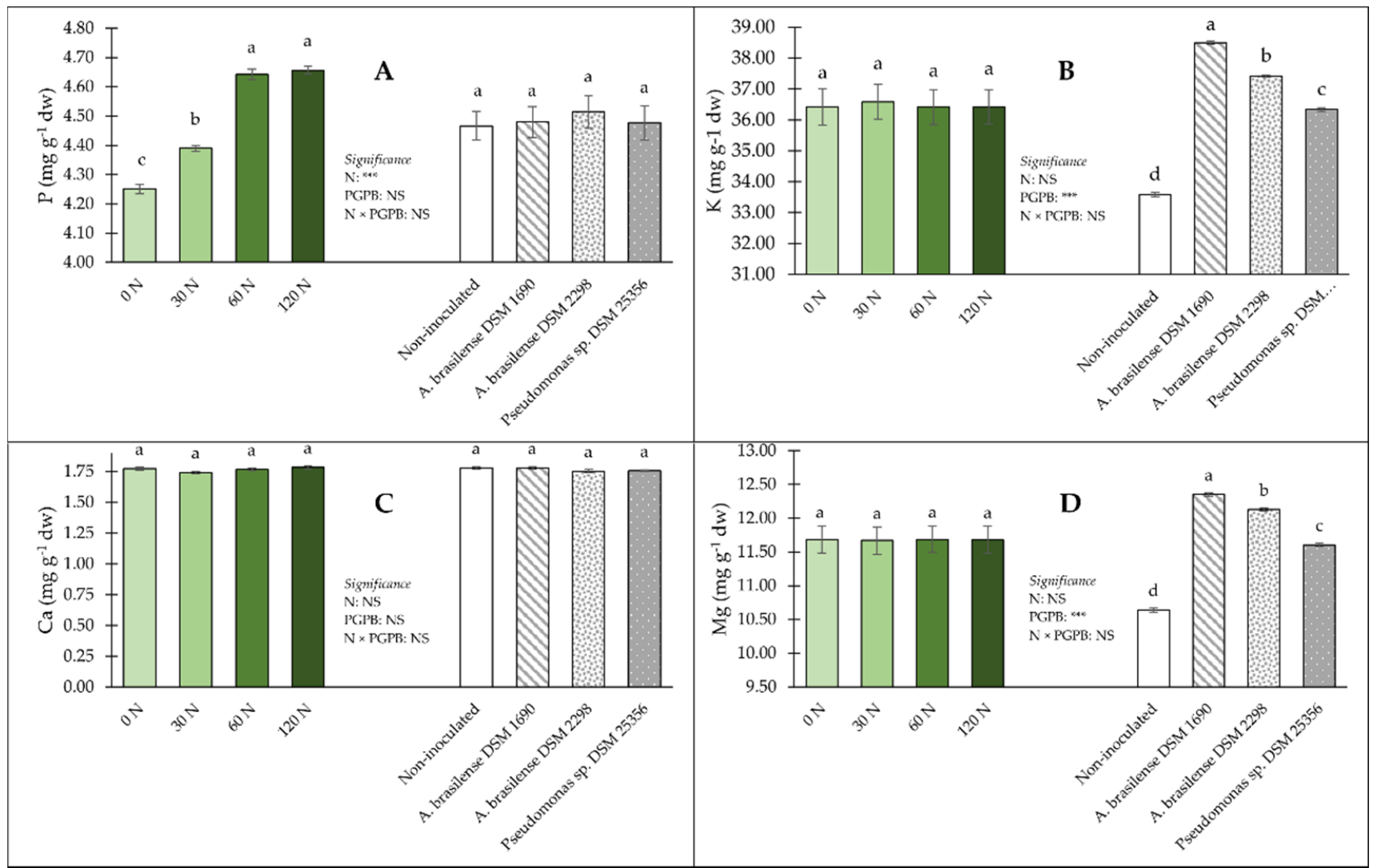

Figure 3. Impact of plant growth promoting bacteria (PGPB) (A. brasilense DSM 1690, A. brasilense DSM 2298 and Pseudomonas sp. DSM 25356) and nitrogen dose $\left(0,30,60\right.$ and $\left.120 \mathrm{~kg} \mathrm{ha}^{-1}\right)$ on phosphorous (P) (A), potassium (K) (B), calcium (Ca) (C) and magnesium (Mg) (D) of 'Canasta' lettuce. Means followed by the same letter for treatments are not significantly different accordingly to Tukey's honestly significant difference (HSD) test at $p \leq 0.05$. Significance levels: NS non-significant; *** significant at $p \leq 0.001$. Bars indicate standard error. $0 \mathrm{~N}, 30 \mathrm{~N}, 60 \mathrm{~N}$ and $120 \mathrm{~N}$ represent $0,30,60$ and $120 \mathrm{~kg} \mathrm{~N} \mathrm{ha}^{-1}$, respectively.

Nitrogen dose and PGPB did not significantly affect Ca concentration (Figure 3C).

Data on $\mathrm{Mg}$ concentration supported the trend presented for K concentration (Figure 3D).

\subsection{Nitrogen Indices}

As regard NUE and UE, ANOVA revealed a significant effect of the interaction $\mathrm{N} \times$ PGPB (Table 4).

Lettuce plants from the combination $30 \times$ A. brasilense DSM 2298 displayed the highest NUE value, followed by those fertigated with $30 \mathrm{~kg} \mathrm{~N}^{-1}$ and inoculated with $A$. brasilense DSM 1690 (Table 4). The lowest NUE was observed in non-inoculated plants fertigated with $120 \mathrm{~kg} \mathrm{~N} \mathrm{ha}^{-1}$.

Plants treated with $A$. brasilense DSM 1690 and fertigated with $30 \mathrm{~kg} \mathrm{~N}^{-1}$ had the highest UE values, followed by those inoculated with $A$. brasilense DSM 2298 and supplied with $30 \mathrm{~kg} \mathrm{~N}$ ha $^{-1}$, which in turn revealed a higher UE value than those inoculated with Pseudomonas sp. DSM 25356 and fed with $30 \mathrm{~kg} \mathrm{~N} \mathrm{ha}^{-1}$ (Table 4). The lowest UE values were recorded from non-inoculated plants and exposed to the highest $\mathrm{N}$ level. 
Table 4. Interaction effect of plant growth promoting bacteria (PGPB) (A. brasilense DSM 1690, A. brasilense DSM 2298 and Pseudomonas sp. DSM 25356) and nitrogen dose (30,60 and $\left.120 \mathrm{~kg} \mathrm{ha}^{-1}\right)$ on nitrogen use efficiency (NUE) and nitrogen utilization efficiency (UE) of 'Canasta' lettuce.

\begin{tabular}{|c|c|c|c|c|c|}
\hline \multicolumn{2}{|r|}{ Treatments } & \multicolumn{2}{|c|}{ NUE (t kg $\left.{ }^{-1}\right)$} & \multicolumn{2}{|c|}{$\mathrm{UE}\left(\mathrm{kg} \mathrm{kg}^{-1}\right)$} \\
\hline $\mathrm{N}$ dose $\left(\mathrm{kg} \mathrm{ha}^{-1}\right)$ & PGPB & & & & \\
\hline \multirow[t]{4}{*}{ 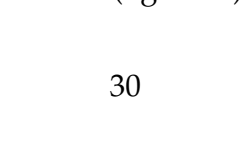 } & Non-inoculated & 3.01 & $\mathrm{~d}$ & 11.00 & $\mathrm{~d}$ \\
\hline & A. brasilense DSM 1690 & 4.01 & $\mathrm{~b}$ & 19.66 & $\mathrm{a}$ \\
\hline & A. brasilense DSM 2298 & 4.45 & a & 18.87 & $b$ \\
\hline & Pseudomonas sp. DSM 25356 & 3.49 & c & 13.92 & C \\
\hline \multirow{4}{*}{60} & Non-inoculated & 1.68 & $\mathrm{~g}$ & 6.70 & $\mathrm{f}$ \\
\hline & A. brasilense DSM 1690 & 1.61 & $\mathrm{~h}$ & 8.50 & $\mathrm{e}$ \\
\hline & A. brasilense DSM 2298 & 1.80 & $\mathrm{f}$ & 8.13 & $\mathrm{e}$ \\
\hline & Pseudomonas sp. DSM 25356 & 1.94 & e & 8.44 & $\mathrm{e}$ \\
\hline \multirow{4}{*}{120} & Non-inoculated & 0.84 & $\mathrm{j}$ & 3.91 & $\mathrm{~h}$ \\
\hline & A. brasilense DSM 1690 & 0.88 & $\mathrm{j}$ & 5.26 & $\mathrm{~g}$ \\
\hline & A. brasilense DSM 2298 & 1.09 & $\mathrm{i}$ & 5.69 & $\mathrm{~g}$ \\
\hline & Pseudomonas sp. DSM 25356 & 1.11 & $\mathrm{i}$ & 5.43 & g \\
\hline \multicolumn{6}{|c|}{ Significance } \\
\hline \multicolumn{2}{|r|}{ Nitrogen $(\mathrm{N})$} & \multicolumn{2}{|c|}{$* * *$} & \multicolumn{2}{|c|}{$* * *$} \\
\hline \multicolumn{2}{|r|}{ PGPB } & \multicolumn{2}{|c|}{$* * *$} & \multicolumn{2}{|c|}{$* * *$} \\
\hline \multicolumn{2}{|r|}{$\mathrm{N} \times \mathrm{PGPB}$} & \multicolumn{2}{|c|}{$* * *$} & \multicolumn{2}{|c|}{$* * *$} \\
\hline
\end{tabular}

Means followed by the same letter for treatments are not significantly different accordingly to Tukey's honestly significant difference (HSD) test at $p \leq 0.05$. Significance levels: ${ }^{* * *}$ significant at $p \leq 0.001$.

\section{Discussion}

Nitrogen supply is a fundamental agronomic practice to guarantee prime growth, development, and yield of any crop. However, the improper use of nitrogen can determine environmental repercussions. Concomitantly, the nitrogen supply and its accumulation in plant tissues are a major issue, especially in vegetables classified as nitrogen iperaccumulators, such as lettuce. Concomitantly, contemporary agriculture must afford the dual mission of sustaining the global population and reducing the ecological effect of the vegetable production sector $[38,39]$. An innovative agronomic practice to face these challenges, is the application of biostimulants, including PGPMs, such as plant growth promoting bacteria (PGPB), which offer an attractive way to substitute chemical fertilisers [40].

Our study highlighted that both plants inoculated with Azospirillum brasilense and fertigated with 30 or $60 \mathrm{~kg} \mathrm{~N} \mathrm{ha}^{-1}$ and those inoculated with Pseudomonas sp. and grown with $120 \mathrm{~kg} \mathrm{~N} \mathrm{ha}^{-1}$, showed the best results in terms of plant vigour traits, yield and head dry matter percentage. These findings are in accord with those reported by Gravel et al. [41], who, by studying the effect of two PGPB (Pseudomonas and Trichoderma genus) on growth and yield of tomato cultivated in greenhouse, found that plants treated with PGPB had higher shoots and roots fresh weight, plant length and fruit yield. Our outcomes are also in agreement with those by Bhattacharyya and Jha [42], who reported that PGPB application significantly enhances plant vigour-related traits and dry matter production in various crops, such as potato and tomato. Furthermore, Singh et al. [43] revealed a beneficial effect of Azospirillum PGPB application on broccoli plant growth features and yield. As reported by Mantelin and Touraine [44], overall, an implementation in $\mathrm{N}$ supply leads to a greater plant $\mathrm{N}$ status, corresponding in a low plant $\mathrm{N}$ request, which limits both the $\mathrm{NO}^{-}{ }_{3}$ transporters and plant development. The same authors [44] stated that the effects of PGPB on $\mathrm{N}$ absorption and plant growth are comparable to those of low $\mathrm{N}$ availability. However, our data on yield and yield-related traits showed that plants treated with A. brasilense (DSM 1690 and DSM 2298 strains) had the best performance when fertigated with the mild N dosages. Thus, we may assume that the highest $\mathrm{N}$ regime inhibited the $A$. brasilense activity. In this respect, we must point out that, currently, the exact mechanisms by which PGPB elicit plant growth and development are not totally understood. However, Parewa et al. [45] 
reported that PGPB have a direct effect on plant growth via several mechanisms, such as, nitrogen fixation, solubilisation of inorganic phosphate and the ability to synthesize plant key hormones.

This study showed that both PGPBs tested exerted a positive effect on SSC. In particular, plants treated with $A$. brasilense had a higher SSC when subjected to mild N levels ( 30 or $60 \mathrm{~kg} \mathrm{ha}^{-1}$ ), whereas plants inoculated with Pseudomonas sp. revealed the highest SSC when fertigated with $120 \mathrm{~kg} \mathrm{~N} \mathrm{ha}^{-1}$. These findings agree with those of Ordookhani and Zare [46] who, investigating on the influence of PGPMs on intrinsic fruit quality parameters in tomato, found a positive effect of the microorganism on fruit SSC. Our data are also in line with those of Katsenios et al. [47], who studied the impact of different PGPB strains on growth, yield and quality of industrial tomato. Generally, our results underlined that SSC parameter is interactively modulated by PGPB application and nitrogen dose.

Vegetable colour is a visual aspect which influences product appeal, as it is directly related to the consumer's perceived quality [48]. Thus, agronomic practices causing colour changes should be taken into consideration, particularly for leafy green vegetables. It is well documented that leaf colour is chiefly related to its chlorophyll concentration, which in turn it is affected by nitrogen availability [49]. However, our data showed that plants cultivated without $\mathrm{N}$ supply had a greener leaf colour than plant fertigated with $\mathrm{N}$. This is related to the fact that 'Canasta' lettuce leaves are characterized by an anthocyanin pigmentation and, consequently, $\mathrm{N}$ dose does not reflect the conventional trend reported for leafy green vegetables.

Our findings indicate that ascorbic acid and total phenolics in lettuce plants were boosted through PGPB inoculation, particularly in plants inoculated with A. brasilense DSM 1690. This finding is sustained by Parewa et al. [45], who stated that PGPB enhance secondary metabolites production. Similarly, Cappellari et al. [50] found that three PGPR genus, including two Pseudomonas and one Bacillus, elicit phenolic biosynthesis of Mentha piperita. Kloepper [51], Van Loon [52] and Babalola [53] reported that numerous PGPR strains trigger plant tolerance to phytopathogens via modification of the secondary metabolism, biosynthesizing phenolic compounds. Data on ascorbic acid and total phenols are in accordance with those of Ottaiano et al. [54] who, by appraising the impact of biostimulant supply under different $\mathrm{N}$ regimes on yield and quality of lettuce, found that ascorbic acid and total phenols contents decrease as $\mathrm{N}$ level increases. Our findings are also supported by Di Mola et al. [55] who, investigating on the interactive effect of seaweed extract application and $\mathrm{N}$ doses, found that ascorbic acid concentration is reduced by a high $\mathrm{N}$ level.

Results revealed that plants treated with A. brasilense DSM 1690 combined with 60 or $120 \mathrm{~kg} \mathrm{~N} \mathrm{ha}^{-1}$ had the highest carotenoids concentration. Similarly, plants treated with A. brasilense DSM 1690 and fertigated with the highest $\mathrm{N}$ level showed the highest total chlorophyll. Our data fully agree with previous studies by Radhakrishnan and Lee [56] who, evaluating the influence of PGPB (Bacillus methylotrophicus KE2) on growth and nutritional metabolites of lettuce, found that PGPB application enhances leaf pigments (total chlorophyll and carotenoids) concentrations. Pinto et al. [57] underlined that chlorophyll and carotenoid concentrations are directly associated to mineral elements in plant. In line to the assumption of Radhakrishnan and Lee [56], the higher pigments concentration in plants treated with A. brasilense DSM 1690 could be linked to the profuse amount of $\mathrm{Mg}$ in plant tissues, since $\mathrm{Mg}$ is a core element in chlorophyll.

Outcomes pointed out that plants colonized by A. brasilense DSM 1690 and associated with the highest $\mathrm{N}$ level $\left(120 \mathrm{~kg} \mathrm{ha}^{-1}\right)$ displayed the highest $\mathrm{N}$ leaf concentration. The macronutrients, like $\mathrm{N}$, can directly and/or indirectly affect cellular formations. The increase of plant $\mathrm{N}$ concentration by PGPB inoculation is extensively reported [56]. In this regard, de Santi Ferrara et al. [58] stated that nitrogen fixation process of microbes in soil is the main reason for this increase. Particularly, Hungria et al. [59] demonstrated that two strains of A. brasilense (Ab-V5 and Ab-V6), had similar nif and fix genes that induce the ability to fix atmospheric $\mathrm{N}$. 
Results showed that PGPB application did not influence P concentration. This finding is coherent with that of Hungria et al. [60] who, assessing the effect of different strains of A. brasilense and A. lipoferum on yield and mineral profile of leaves and grains in maize and wheat, found that PGPB does not significantly affect $P$ concentration in leaves tissue. Data also showed that plants fertigated with 60 or $120 \mathrm{~kg} \mathrm{~N}$ ha $^{-1}$ had the highest leaf $\mathrm{P}$ concentration. This agrees with precedent studies evaluating the influence of the combined treatment of Trichoderma virens and biostimulant on lettuce grown under various $\mathrm{N}$ regimes [61]. Findings on $\mathrm{K}$ and $\mathrm{Mg}$ concentrations revealed that PGPB elicit their accumulation in plant tissues. These results are totally in accord with those of Radhakrishnan and Lee [56], who associated these results to a catalysed metabolism of proteins, enzymes, lipids and nucleic acids. Furthermore, our data displayed that $\mathrm{Ca}$ leaf concentration was not affected neither by PGPB action nor by $\mathrm{N}$ level. These findings completely agree with those reported by Hungria et al. [60] and by Rouphael et al. [61].

Data revealed that plants colonized with PGPB had a higher total sugar concentration than non-inoculated plants. In this respect, our results are in accord with those of Sandhya et al. [62] who, by studying the effect of PGPB (Pseudomonas spp.) on compatible solutes, antioxidant status and plant growth of maize under drought stress, found that PGPB colonization enhances total soluble sugars. Furthermore, in agreement with our outcome, Pirlak and Köse [63] reported that PGPR improved total sugars in strawberry fruits. However, our data highlighted that $\mathrm{N}$ dose did not significantly influence total sugars. These results are coherent with those of Bénard et al. [64] who reported that $N$ availability does not significantly influence tomato fruit sugars concentration.

Data revealed that the PGPB tested increased NUE indices (NUE and UE) under N deficit. These data are fully corroborated by Zeffa et al. [65], who found that A. brasilense increases NUE of maize genotypes through an increased plants growth and development. The beneficial effect of $A$. brasilense on lettuce, under low $\mathrm{N}$ regime, emphasise the importance of PGPB to overcome plant developmental limits under suboptimal-growth conditions.

\section{Conclusions}

The use of PGPB to enhance crop yield under optimal or suboptimal growth conditions is acquiring importance in the sector of leafy vegetable production due to PGPB capacity to increase the business profit and, concomitantly, reduce environmental impact of the conventional cultivation practices adopted by growers. The inoculation of PGPB, particularly A. brasilense DSM 2298, boosted plant growth and productivity mainly under low $\mathrm{N}$ doses. The application of both $A$. brasilense strains was efficient in sustaining better nutritional and functional status of lettuce in terms of the SSC, ascorbic acid, total phenolics, carotenoids, total chlorophyll and total sugars. Remarkably, $\mathrm{K}$ and $\mathrm{Mg}$ concentrations can be enhanced by PGPB, expressly by A. brasilense DSM 1690. A. brasilense increased N concentration in lettuce leaves; however, it also enhanced NUE and UE by $47.8 \%$ and $78.7 \%$, respectively, compared with the control. The findings of the present study underline the advantage of applying PGPB in 'Canasta' lettuce plants to increase crop yield and quality under optimal and suboptimal $\mathrm{N}$ levels. This information can be beneficial both to the growers and the ecosystem sustainability.

Author Contributions: Conceptualization, B.B.C., L.S., G.I. and P.A.; methodology, B.B.C., S.A., L.S., Y.R., G.I. and P.A.; software, B.B.C., S.A., L.S. and G.N.; validation, Y.R., G.N., G.I. and L.S.; formal analysis, B.B.C., C.D.P. and L.S.; investigation, B.B.C., C.D.P., P.A. and L.S.; resources, G.I. and L.S.; data curation, B.B.C., S.A., Y.R., G.N. and L.S.; writing-original draft preparation, B.B.C. and L.S; writing-review and editing, Y.R., G.N., G.I. and L.S.; visualization, Y.R., G.N., G.I. and L.S.; supervision, G.I. and L.S.; project administration, G.I. and L.S.; funding acquisition, C.D.P., G.I. and L.S. All authors have read and agreed to the published version of the manuscript.

Funding: This research received no external funding.

Institutional Review Board Statement: Not applicable.

Informed Consent Statement: Not applicable. 


\section{Data Availability Statement: Not applicable.}

Acknowledgments: The authors thank Mugavero fertilizer for providing the PGPB and the N fertilizer used in this study and the farm VIVAIO Conca D'Oro F.lli Romano for hosting the trial.

Conflicts of Interest: The authors declare no conflict of interest.

\section{References}

1. Mou, B. Lettuce. In Vegetables I; Prohens, J., Nuez, F., Eds.; Springer: New York, NY, USA, 2008; pp. 75-116.

2. Sabatino, L.; Consentino, B.B.; Rouphael, Y.; De Pasquale, C.; Iapichino, G.; D'Anna, F.; La Bella, S. Protein Hydrolysates and Mo-Biofortification Interactively Modulate Plant Performance and Quality of 'Canasta' Lettuce Grown in a Protected Environment. Agronomy 2021, 11, 1023. [CrossRef]

3. FAOSTAT. Available online: https:/ /www.fao.org/faostat/en/\#data (accessed on 17 November 2021).

4. Kim, M.J.; Moon, Y.; Tou, J.C.; Mou, B.; Waterland, N.L. Nutritional value, bioactive compounds and health benefits of lettuce (Lactuca sativa L.). J. Food Compos. Anal. 2016, 49, 19-34. [CrossRef]

5. Ciriello, M.; Formisano, L.; Pannico, A.; El-Nakhel, C.; Fascella, G.; Duri, L.G.; Cristofano, F.; Gentile, B.R.; Giordano, M.; Rouphael, Y.; et al. Nutrient Solution Deprivation as a Tool to Improve Hydroponics Sustainability: Yield, Physiological, and Qualitative Response of Lettuce. Agronomy 2021, 11, 1469. [CrossRef]

6. El-Nakhel, C.; Pannico, A.; Kyriacou, M.C.; Giordano, M.; De Pascale, S.; Rouphael, Y. Macronutrient deprivation eustress elicits differential secondary metabolites in red and green-pigmented butterhead lettuce grown in a closed soilless system. J. Sci. Food Agric. 2019, 99, 6962-6972. [CrossRef]

7. Li, Z.; Zhao, X.; Sandhu, A.K.; Gu, L. Effects of exogenous abscisic acid on yield, antioxidant capacities, and phytochemical contents of greenhouse grown lettuces. J. Agric. Food Chem. 2010, 58, 6503-6509. [CrossRef]

8. Luz, G.L.; Medeiros, S.L.P.; Manfron, P.A.; Amaral, A.D.; Muller, L.; Torrez, M.G.; Mentges, L.A. The nitrate issue in hydroponic lettuce and the human health. Ciência Rural 2008, 38, 2388-2394. [CrossRef]

9. Romani, A.; Pinelli, P.; Galardi, C.; Sani, G.; Cimato, A.; Heimler, D. Polyphenols in greenhouse and open-air-grown lettuce. Food Chem. 2002, 79, 337-342. [CrossRef]

10. Miceli, A.; Vetrano, F.; Sabatino, L.; D'Anna, F.; Moncada, A. Influence of Preharvest Gibberellic Acid Treatments on Postharvest Quality of Minimally Processed Leaf Lettuce and Rocket. Horticulturae 2019, 5, 63. [CrossRef]

11. Sabatino, L.; La Bella, S.; Ntatsi, G.; Iapichino, G.; D'Anna, F.; De Pasquale, C.; Consentino, B.B.; Rouphael, Y. Selenium biofortification and grafting modulate plant performance and functional features of cherry tomato grown in a soilless system. Sci. Hortic. 2021, 285, 110095. [CrossRef]

12. Mauro, R.P.; Agnello, M.; Distefano, M.; Sabatino, L.; San Bautista Primo, A.; Leonardi, C.; Giuffrida, F. Chlorophyll Fluorescence, Photosynthesis and Growth of Tomato Plants as Affected by Long-Term Oxygen Root Zone Deprivation and Grafting. Agronomy 2020, 10, 137. [CrossRef]

13. Solaiman, A.R.M.; Rahbbani, M.G. Effect of NPKS and cow dung on growth and yield of tomato. Bull. Inst. Trop. Agric. Kyushu Univ. 2006, 29, 31-37.

14. Zaidi, A.; Ahmad, E.; Khan, M.S.; Saif, S.; Rizvi, A. Role of Plant Growth Promoting Rhizobacteria in Sustainable Production of Vegetables: Current Perspective. Sci. Hortic. 2015, 193, 231-239. [CrossRef]

15. Sabatino, L.; Iapichino, G.; La Bella, S.; Tuttolomondo, T.; D’Anna, F.; Cardarelli, M.; Consentino, B.B.; Rouphael, Y. An Appraisal of Calcium Cyanamide as Alternative N Source for Spring-Summer and Fall Season Curly Endive Crops: Effects on Crop Performance, NUE and Functional Quality Components. Agronomy 2020, 10, 1357. [CrossRef]

16. Sabatino, L.; Iapichino, G.; Consentino, B.B.; D'Anna, F.; Rouphael, Y. Rootstock and Arbuscular Mycorrhiza Combinatorial Effects on Eggplant Crop Performance and Fruit Quality under Greenhouse Conditions. Agronomy 2020, 10, 693. [CrossRef]

17. Consentino, B.B.; Virga, G.; La Placa, G.G.; Sabatino, L.; Rouphael, Y.; Ntatsi, G.; Iapichino, G.; La Bella, S.; Mauro, R.P.; D'Anna, F.; et al. Celery (Apium graveolens L.) Performances as Subjected to Different Sources of Protein Hydrolysates. Plants 2020, $9,1633$. [CrossRef]

18. La Bella, S.; Consentino, B.B.; Rouphael, Y.; Ntatsi, G.; De Pasquale, C.; Iapichino, G.; Sabatino, L. Impact of Ecklonia Maxima Seaweed Extract and Mo Foliar Treatments on Biofortification, Spinach Yield, Quality and NUE. Plants 2021, 10, 1139. [CrossRef] [PubMed]

19. Davison, J. Plant Beneficial Bacteria. Nat. Biotechnol. 1988, 6, 282-286. [CrossRef]

20. Kloepper, J.W.; Lifshitz, R.; Zablotowicz, R.M. Free-Living Bacterial Inocula for Enhancing Crop Productivity. Trends Biotechnol. 1989, 7, 39-44. [CrossRef]

21. Cassan, F.; García de Salamone, I. Azospirillum: Cell Physiology, Plant Response, Agronomic and Environmental Research in Argentina; Asociación Argentina de Microbiologia: Dean Funes, Argentina, 2008; ISBN 978-987-98475-8-9.

22. Tien, T.M.; Gaskins, M.H.; Hubbell, D.H. Plant growth substances produced by Azospirillum brasilense and their effect on the growth of pearl millet (Pennisetum Americanum L.). Appl. Environ. Microbiol. 1979, 37, 1016-1024. [CrossRef] [PubMed]

23. Bottini, R.; Fulchieri, M.; Pearce, D.; Pharis, R. Identification of gibberelins A1, A3, and iso-A3 in cultures of A. lipoferum. Plant Physiol. 1989, 90, 45-47. [CrossRef] [PubMed] 
24. Strzelczyk, E.; Kamper, M.; Li, C. Cytocinin-like-substances and ethylene production by Azospirillum in media with different carbon sources. Microbiol. Res. 1994, 149, 55-60. [CrossRef]

25. Rodriguez, H.; Gonzalez, T.; Goire, I.; Bashan, Y. Gluconic Acid Production and Phosphate Solubilization by the Plant GrowthPromoting Bacterium Azospirillum spp. Naturwissenschaften 2004, 91, 552-555. [CrossRef] [PubMed]

26. Correa, O.S.; Romero, A.M.; Soria, M.A.; de Estrada, M. Azospirillum brasilense-plant genotype interactions modify tomato response to bacterial diseases, and root and foliar microbial communities. In Azospirillum sp.: Cell Physiology, Plant Interactions and Agronomic Research in Argentina; Cassán, F.D., Garcia de Salamone, I., Eds.; Asociación Argentina de Microbiologia: Dean Funes, Argentina, 2008; Volume 266, pp. 85-94.

27. Weller, D.M.; Thomashow, L.S. Current Challenges in Introducing Beneficial Microorganisms into the Rhizosphere. In Molecular Ecology of Rhizosphere Microorganisms; John Wiley \& Sons, Ltd.: Hoboken, NJ, USA, 1994; pp. 1-18. ISBN 978-3-527-61581-0.

28. Glick, B.R. The enhancement of plant growth by freeliving bacteria. Can. J. Microbiol. 1995, 41, 109-117. [CrossRef]

29. Probanza, A.; Lucas, J.A.; Acero, N.; Gutierrez Mañero, F.J. The Influence of Native Rhizobacteria on European Alder (Alnus Glutinosa L. Gaertn.) Growth. Plant Soil 1996, 182, 59-66. [CrossRef]

30. Dobereiner, J.; Pedrosa, F.O. Nitrogen-Fixing Bacteria in Nonleguminous Crop Plants; Brock/Springer Series in Contemporary Bioscience; Science Tech Publishers: Hampshire, UK, 1987; pp. 1-155.

31. Broadley, M.R.; Escobar-Gutièrrez, A.J.; Burns, A.; Burns, G. What are the effects of nitrogen deficiency on growth components of lettuce? New Phytol. 2000, 147, 519-526. [CrossRef] [PubMed]

32. Tesi, R. Orticoltura Mediterranea Sostenibile; Pàtron Editore: Bologna, Italy, 2010.

33. Meda, A.; Lamien, C.E.; Romito, M.; Millogo, J.; Nacoulma, O.G. Determination of the total phenolic, flavonoid and proline contents in Burkina Fasan honey, as well as their radical scavenging activity. Food Chem. 2005, 91, 571-577. [CrossRef]

34. Serna, M.; Hernández, F.; Coll, F.; Coll, Y.; Amorós, A. Effects of brassinosteroid analogues on total phenols, antioxidant activity, sugars, organic acids and yield of field grown endive (Cichorium endivia L.). J. Sci. Food Agric. 2013, 93, 1765-1771. [CrossRef]

35. Costache, M.A.; Campeanu, G.; Neata, G. Studies concerning the extraction of chlorophyll and total carotenoids from vegetables. Rom. Biotechnol. Lett. 2012, 17, 7702-7708.

36. Fogg, D.N.; Wilkinson, A.N. The colorimetric determination of phosphorus. Analyst 1958, 83, 406-414. [CrossRef]

37. Morand, P.; Gullo, J.L. Mineralisation des tissus vegetaux en vue du dosage de P, Ca, Mg, Na, K. Ann. Agron. 1970, $21,229-236$.

38. Colla, G.; Cardarelli, M.; Bonini, P.; Rouphael, Y. Foliar Applications of Protein Hydrolysate, Plant and Seaweed Extracts Increase Yield but Differentially Modulate Fruit Quality of Greenhouse Tomato. Horts 2017, 52, 1214-1220. [CrossRef]

39. Searchinger, T.; Hanson, C.; Ranganathan, J.; Lipinski, B.; Waite, R.; Winterbottom, R.; Dinshaw, A.; Heimlich, R. The Great Balancing Act; World Resources Institite: Washington, DC, USA, 2013.

40. Zaidi, A.; Khan, M.S. Microbial Strategies for Vegetable Production; Springer International Publishing: Cham, Switzerland, 2017; ISBN 978-3-319-54400-7.

41. Gravel, V.; Antoun, H.; Tweddell, R.J. Growth Stimulation and Fruit Yield Improvement of Greenhouse Tomato Plants by Inoculation with Pseudomonas Putida or Trichoderma Atroviride: Possible Role of Indole Acetic Acid (IAA). Soil Biol. Biochem 2007, 39, 1968-1977. [CrossRef]

42. Bhattacharyya, P.N.; Jha, D.K. Plant Growth-Promoting Rhizobacteria (PGPR): Emergence in Agriculture. World J. Microbiol. Biotechnol. 2012, 28, 1327-1350. [CrossRef]

43. Singh, A.; Maji, S.; Kumar, S. Effect of biofertilizers on yield and biomolecules of anti-cancerous vegetable broccoli. Int. J. Bio-Resour. Stress Manag. 2014, 5, 262-268. [CrossRef]

44. Mantelin, S.; Touraine, B. Plant Growth-promoting Bacteria and Nitrate Availability: Impacts on Root Development and Nitrate Uptake. J. Exp. Bot. 2004, 55, 27-34. [CrossRef] [PubMed]

45. Parewa, H.P.; Yadav, J.; Rakshit, A.; Meena, V.S.; Karthikeyan, N. Plant growth promoting rhizobacteria enhance growth and nutrient uptake of crops. Agric. Sustain. Dev. 2014, 2, 101-116.

46. Ordookhani, K.; Zare, M. Effect of Pseudomonas, Azotobacter and arbuscular mycorrhiza fungi on lycopene, antioxidant activity and total soluble solid in tomato (Lycopersicon esculentum F1 Hybrid, Delba). Adv. Environ. Biol. 2011, 5, 1290-1294.

47. Katsenios, N.; Andreou, V.; Sparangis, P.; Djordjevic, N.; Giannoglou, M.; Chanioti, S.; Stergiou, P.; Xanthou, M.-Z.; Kakabouki, I.; Vlachakis, D.; et al. Evaluation of Plant Growth Promoting Bacteria Strains on Growth, Yield and Quality of Industrial Tomato. Microorganisms 2021, 9, 2099. [CrossRef]

48. Fernández-Vázquez, R.; Stinco, C.M.; Meléndez-Martínez, A.J.; Heredia, F.J.; Vicario, I.M. Visual and Instrumental Evaluation of Orange Juice Color: A Consumers' Preference Study. J. Sens. Stud. 2011, 26, 436-444. [CrossRef]

49. Bojović, B.; Marković, A. Correlation between nitrogen and chlorophyll content in wheat (Triticum aestivum L.). Kragujev. J. Sci. 2009, 31, 69-74.

50. Cappellari, L.d.R.; Chiappero, J.; Santoro, M.V.; Giordano, W.; Banchio, E. Inducing Phenolic Production and Volatile Organic Compounds Emission by Inoculating Mentha Piperita with Plant Growth-Promoting Rhizobacteria. Sci. Hortic. 2017, 220, 193-198. [CrossRef]

51. Kloepper, J.W. Plant-growth-promoting rhizobacteria as biological control agents. In Metting Soil Microbial Ecology: Applications in Agricultural and Environmental Management; Marcel Dekker Inc.: New York, NY, USA, 1993; pp. 255-273.

52. Van Loon, L.C. Plant response to plant growth-promoting rhizobacteria. Eur. J. Plant Pathol. 2007, 119, 243-254. [CrossRef]

53. Babalola, O.O. Beneficial bacteria of agricultural importance. Biotechnol. Lett. 2010, 32, 1559-1570. [CrossRef] 
54. Ottaiano, L.; Di Mola, I.; Cozzolino, E.; El-Nakhel, C.; Rouphael, Y.; Mori, M. Biostimulant Application under Different Nitrogen Fertilization Levels: Assessment of Yield, Leaf Quality, and Nitrogen Metabolism of Tunnel-Grown Lettuce. Agronomy 2021, 11, 1613. [CrossRef]

55. Di Mola, I.; Cozzolino, E.; Ottaiano, L.; Giordano, M.; Rouphael, Y.; Colla, G.; Mori, M. Effect of vegetal- and seaweed extractbased biostimulants on agronomical and leaf quality traits of plastic tunnel-grown baby lettuce under four regimes of nitrogen fertilization. Agronomy 2019, 9, 571. [CrossRef]

56. Radhakrishnan, R.; Lee, I.J. Gibberellins producing Bacillus methylotrophicus KE2 supports plant growth and enhances nutritional metabolites and food values of lettuce. Plant Physiol. Biochem. 2016, 109, 181-189. [CrossRef]

57. Pinto, E.; Almeida, A.A.; Aguiar, A.A.R.M.; Ferreira, I.M.P.L.V.O. Changes in Macrominerals, Trace Elements and Pigments Content during Lettuce (Lactuca Sativa L.) Growth: Influence of Soil Composition. Food Chem. 2014, 152, 603-611. [CrossRef] [PubMed]

58. de Santi Ferrara, F.I.; Oliveira, Z.M.; Gonzales, H.H.S.; Floh, E.I.S.; Barbosa, H.R. Endophytic and Rhizospheric Enterobacteria Isolated from Sugar Cane Have Different Potentials for Producing Plant Growth-Promoting Substances. Plant Soil 2012, 353, 409-417. [CrossRef]

59. Hungria, M.; Ribeiro, R.A.; Nogueira, M.A. Draft Genome Sequences of Azospirillum Brasilense Strains Ab-V5 and Ab-V6, Commercially Used in Inoculants for Grasses and Legumes in Brazil. Genome Announc. 2018, 6, e00393-18. [CrossRef] [PubMed]

60. Hungria, M.; Campo, R.J.; Souza, E.M.; Pedrosa, F.O. Inoculation with Selected Strains of Azospirillum Brasilense and A. Lipoferum Improves Yields of Maize and Wheat in Brazil. Plant Soil 2010, 331, 413-425. [CrossRef]

61. Rouphael, Y.; Carillo, P.; Colla, G.; Fiorentino, N.; Sabatino, L.; El-Nakhel, C.; Giordano, M.; Pannico, A.; Cirillo, V.; Shabani, E.; et al. Appraisal of Combined Applications of Trichoderma virens and a Biopolymer-Based Biostimulant on Lettuce Agronomical, Physiological, and Qualitative Properties under Variable N Regimes. Agronomy 2020, 10, 196. [CrossRef]

62. Sandhya, V.; Ali, S.Z.; Grover, M.; Reddy, G.; Venkateswarlu, B. Effect of Plant Growth Promoting Pseudomonas spp. on Compatible Solutes, Antioxidant Status and Plant Growth of Maize under Drought Stress. Plant Growth Regul. 2010, 62, 21-30. [CrossRef]

63. Pırlak, L.; Köse, M. Effects of Plant Growth Promoting Rhizobacteria on Yield and Some Fruit Properties of Strawberry. J. Plant Nutr. 2009, 32, 1173-1184. [CrossRef]

64. Bénard, C.; Gautier, H.; Bourgaud, F.; Grasselly, D.; Navez, B.; Caris-Veyrat, C.; Weiss, M.; Génard, M. Effects of Low Nitrogen Supply on Tomato (Solanum Lycopersicum) Fruit Yield and Quality with Special Emphasis on Sugars, Acids, Ascorbate, Carotenoids, and Phenolic Compounds. J. Agric. Food Chem. 2009, 57, 4112-4123. [CrossRef] [PubMed]

65. Zeffa, D.M.; Perini, L.J.; Silva, M.B.; de Sousa, N.V.; Scapim, C.A.; de Oliveira, A.L.M.; Júnior, A.T.D.; Gonçalves, L.S.A. Azospirillum brasilense Promotes Increases in Growth and Nitrogen Use Efficiency of Maize Genotypes. PLoS ONE 2019, 14, e0215332. [CrossRef] 